\title{
Detection of Cryptosporidium spp. in Diarrheic Immunocompetent Patients in Beni-Suef, Egypt: Insight into Epidemiology and Diagnosis
}

\author{
Samah S. Abdel Gawad', Mousa A. M. Ismail², Naglaa F. A. Imam², Ahmed H. A. Eassa',*, Enas Yahia abu-Sarea' \\ ${ }^{1}$ Parasitology Department, Faculty of Medicine, Beni-Suef University, Egypt; ${ }^{2}$ Parasitology Department, Faculty of Medicine, Cairo University, Egypt
}

\begin{abstract}
Cryptosporidium species is an important cause of gastrointestinal infections globally. This study aimed to shed light on its role in diarrheic immunocompetent patients in Beni-Suef, Egypt and to compare three diagnostic methods. Two hundred diarrheic patients, $37 \pm 16.8$ year old, were enrolled. Stool samples were examined by light microscopy, using modified Ziehl-Neelsen stain (MZN) for Cryptosporidium spp. oocysts. Coproantigens were detected by sandwich ELISA. DNA molecular diagnosis was done by nested PCR. PCR yielded the highest detection rates (21.0\%), compared to ELISA (12.5\%) and MZN staining method (9.5\%). The higher infection rates were in $20-40$ year-old group, followed by 40-60 year-old. Association between epidemiologic factors was statistically not significant; positivity and gender, clinical manifestations, residence, source or water, or contact with animals. Cryptosporidiosis is an important enteric parasitic infection in Beni-Suef and PCR remains the gold standard for diagnosis.
\end{abstract}

Key words: Cryptosporidium, Beni-Suef, PCR, ELISA, modified Ziehl-Neelsen stain

\section{INTRODUCTION}

Cryptosporidium is a protozoan parasite involved in waterborne gastrointestinal infections. The disease usually is mild in immunocompetent patients [1,2]. Moreover, recent studies into the global causes of severe diarrhea in young children have identified the protozoan parasite Cryptosporidium as the second most important diarrheal pathogen after rotavirus $[3,4]$.

The intake of unwholesome water could have devastating effects on our health, as unsafe drinking water is a key determinant of many microbial diseases with serious complications in immunocompetent and immunocompromised individuals $[5,6]$. Many pathogens are readily transmitted through drinking water including Cryptosporidium spp [7,8]. The presence of such parasites in drinking water is partly due to 4 reasons: Firstly, these organisms are indigenous pathogens found in most domestic animals; secondly, the degree of environmental

\footnotetext{
- Received 6 October 2017, revised 17 April 2018, accepted 17 April 2018.

*Corresponding author (ahmegy@hotmail.com)

(C) 2018, Korean Society for Parasitology and Tropical Medicine

This is an Open Access article distributed under the terms of the Creative Commons

Attribution Non-Commercial License (http://creativecommons.org/licenses/by-nc/4.0) which permits unrestricted non-commercial use, distribution, and reproduction in any

medium, provided the original work is properly cited.
}

contamination with their infective stages; thirdly, their resistance to water purification processes and finally unhygienic handling of drinking water $[9,10]$. Contrary to infection in the immunocompromised, cryptosporidiosis in otherwise healthy individuals is generally characterized by self-limited diarrhea, abdominal pain, weight loss, anorexia, fatigue, joint pain, vomiting and fever [10-12].

Laboratory diagnosis of cryptosporidiosis in stool samples depends on microscopic examination of stained slides, the most widely stain used is modified Ziehl-Neelsen (MZN), with a sensitivity of about $75 \%[13,14]$. Other used methods include direct fluorescent antibody assay and coproantigen detection by immunochromatography [15-19]. High sensitivity and specificity for diagnosis was also reported with sandwich coproantigen detection by enzyme-linked immunosorbent assay (ELISA) $[17,20]$ and molecular methods using polymerase chain reaction (PCR), targeting various genes, proteins and glycoproteins [21-24].

Few studies have been conducted in Beni-Suef, Egypt, on cryptosporidiosis in diarrhoeic apparently healthy patients [25]. Thus, this study aimed to document the occurrence of $C$. parvum among individual having diarrhea, at Beni-Suief University Hospital, using conventional copro-parasitological methods versus immunodiagnostic and molecular methods. It 
also aimed to develop guidelines for the investigation of diarrheic stool for the detection of $C$. parvum in such patients. Due to its high sensitivity and specificity, PCR has been put forward as the current gold standard [21,26-28]. Hence, it was chosen to be used in the current study for diagnosis of cryptosporidiosis, along with sandwich ELISA and microscopic examination of stool samples of the enrolled patients.

\section{MATERIALS AND METHODS}

\section{Study population and ethical considerations}

This was a cross-sectional study carried on stool samples from 200 diarrheic patients attending outpatient clinics of Beni-Suef University hospitals, from May 2015 to March 2016.

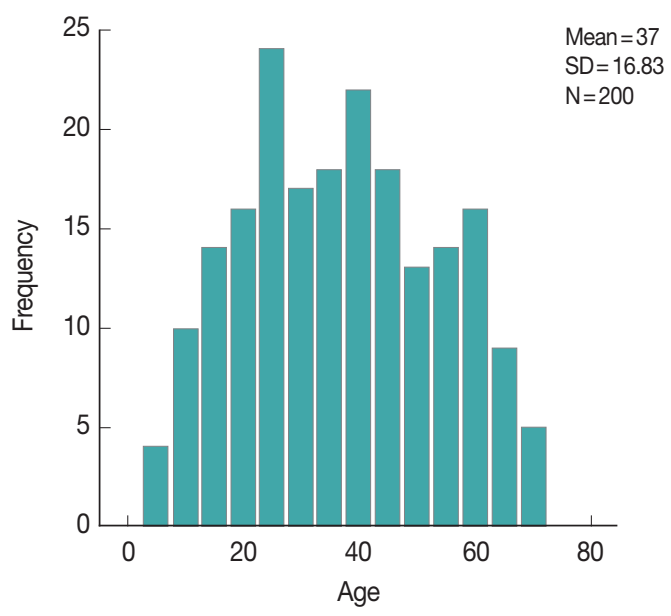

Fig. 1. Graphic representation of age distribution of study population.

Table 1. Descriptive statistics of patients' demographics and history data

\begin{tabular}{llr}
\hline & Variable & No. (\%) \\
\hline Gender & Male & $120(60.0)$ \\
& Female & $80(40.0)$ \\
Residence & Urban & $81(40.5)$ \\
& Rural & $119(59.5)$ \\
Animals at home & Yes & $145(72.5)$ \\
& No & $55(27.5)$ \\
Source of water & Tap water & $172(86.0)$ \\
& Filtered & $28(14.0)$ \\
Clinical & Abdominal pain & $130(65.0)$ \\
manifestations & Abdominal pain and vomiting & $32(16.0)$ \\
& Abdominal pain and flatulence & $10(5.0)$ \\
& Vomiting and fever & $16(8.0)$ \\
& Flatulence & $1(0.5)$ \\
& Abdominal pain, flatulence and fever & $1(0.5)$ \\
& Abdominal pain and tenesmus & $10(5.0)$ \\
\hline
\end{tabular}

The enrolled patients were from various age groups and both sexes (Fig. 1). Their demographic, history and clinical manifestations data are displayed in Tables 1, 2. The enrolled subjects were from various age groups with a mean age of 37 years ( \pm 16.8 SD). Males comprised $60 \%$ of the study subjects. The majority of the study patients was from rural areas, with access to tap water and reported the presence of domestic animals in proximity. The patients' diarrhea had a mean duration of 3.8 days, with a mean of 8.5 for bowel movements. The main symptom reported was abdominal pain (194 patients, 97\%), followed by vomiting (33 patients, 16.5\%), fever (17 patients, $8.5 \%$ ), flatulence (11 patients, 5.5\%), and tenesmus (10 patients, 5\%).

The study was approved by the ethical committee of Faculty of Medicine, Beni-Suef University and informed consent was obtained from patients or their relatives and parents of children. In addition, they responded to questionnaires related to history.

\section{Sample collection and microscopy}

A single fecal sample was obtained from each case. Then, Sheather's sugar floatation concentration technique was done on part of the samples for microscopic examination. Also, acid-fast stained slides were examined for Cryptosporidium oocysts [29]. The remaining parts of the specimens were stored at $-20^{\circ} \mathrm{C}$ for copro-immunoassays and molecular studies.

\section{Coproantigen detecting ELISA}

The frozen stool samples were subjected to Cryptosporidium coproantigen detection using sandwich ELISA (RIDASCREEN Cryptosporidium R-Biopharm Ag, Darmstadt, Germany) according to the manufacturer's instructions. In brief, the test employs specific antibodies in a sandwich-type method. With the presence of Cryptosporidium antigens in a specimen, immobilized antibodies and the conjugated antibody form a sandwich complex. In order to establish a cut-off, 0.15 extinction units

Table 2. Cryptosporidium positive samples by PCR, ELISA, and microscopy using MZN stain

\begin{tabular}{llr}
\hline Test used & Status & No. (\%) \\
\hline PCR & Positive & $42(21.0)$ \\
& Negative & $158(79.0)$ \\
ELISA & Positive & $25(12.5)$ \\
& Negative & $175(87.5)$ \\
Microscopy using MZN & Positive & $19(9.5)$ \\
& Negative & $181(90.5)$ \\
\hline
\end{tabular}


were added to the measured extinction of the negative control. Cut-off $=$ extinction for the negative control +0.15 . A specimen was considered positive if the extinction rate was more than $10 \%$ higher than the calculated cut-off value.

\section{DNA extraction and nested PCR}

Genomic DNA was extracted from the remaining frozen fecal samples using the FavorPrep Stool DNA Isolation Mini Kit (Favorgen Biotech, Ping-Tung, Taiwan) according to the manufacturer's instructions. The samples were treated with thermal shock ( 5 cycles of deep freezing and boiling in a water bath, each for $5 \mathrm{~min}$ ), incubated at $56^{\circ} \mathrm{C}$ for $10 \mathrm{~min}$ and prolonged for $1 \mathrm{hr}$ at $95^{\circ} \mathrm{C}$. Copro-DNA was extracted and amplified by nested PCR (nPCR) targeting COWP gene using two sets of primers: external primers, BCOWPF (5'-ACCGCTTCTCAACAACCATCTTGTCCTC-3') and B C O W P R (5'-CGCACCTGTTCCCACTCAATGTAAACCC-3'), which amplified a 796-bp fragment [30]. A nested primer set cry-15 (5'-GTAGATAATGGAAGAGATTGTG-3') and cry-9 (5'-GGACTGAA ATACAGGCATTATCTTG-3') amplified a 553-bp fragment [31]. The amplified products were qualified by $1.5 \%$ agarose gel electrophoresis and ethidium bromide staining.

\section{Statistical analysis}

Data were analyzed using SPSS $\odot$ Statistics version 24 (SPSS, Armonk, New York, USA). Skewed numerical data were presented as median and interquartile range and difference between groups was compared using the Mann-Whitney test (for 2-group comparison). Categorical variables were presented as number and percentage. Chi-square test, Fisher's exact test, and Likelihood ratio tests were used to compare nominal data and the chi-squared test for trend to compare ordinal data. $P$ value was considered statistically significant if $P<0.05$. Receiver operating characteristics (ROC) with area under the curve analysis were used to confirm specificity and sensitivity of the diagnostic tests.

\section{RESULTS}

Table 2 shows the results of the examination of the stool samples by the 3 used methods in the study, with PCR as the gold standard (considered 100\% sensitive and specific). On exploring the association between PCR and ELISA (Table 3), there was a statistically significant association between both test results $(P<0.0001)$ as well as a statistically significant positive agreement between them (Cohen's Kappa value 0.6-Pvalue $<0.0001$ ).

On evaluating the diagnostic accuracy of ELISA in the current study, the test sensitivity was found to be $57.14 \%$, test specificity was $99.3 \%$, positive predictive value was $96 \%$ and negative predictive value was $89.7 \%$. Microscopy with MZN staining had inferior sensitivity but $100 \%$ specificity and a comparable NPV to ELISA.

Fig. 2 depicts nested PCR results, negative and positive controls, as revealed by agarose gel electrophoresis. As for diagno-

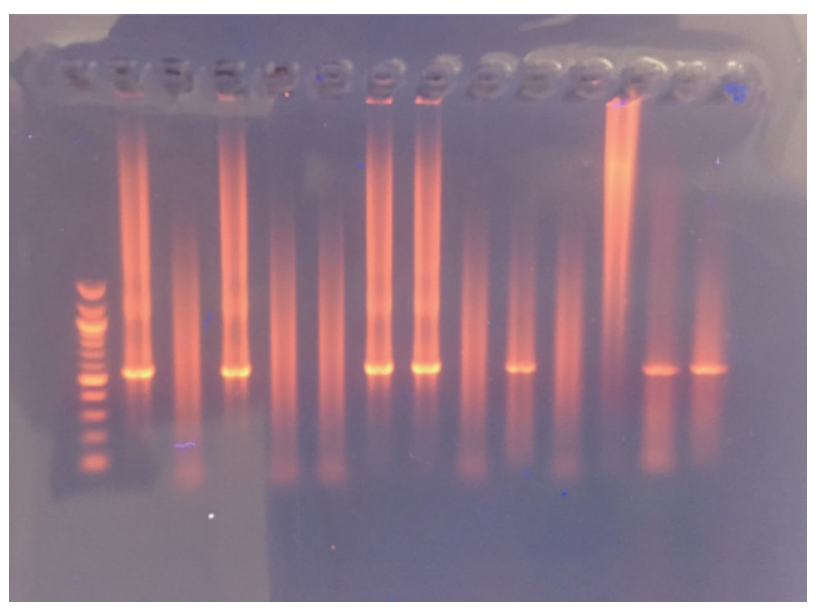

Fig. 2. Agarose gel electrophoresis and nPCR results.

Table 3. Comparison between PCR, ELISA, and microscopy results using MZN stain

\begin{tabular}{|c|c|c|c|c|c|c|c|c|c|}
\hline \multirow[b]{2}{*}{ Tests used } & & \multicolumn{2}{|c|}{ PCR } & \multirow[b]{2}{*}{$P$-value } & \multirow{2}{*}{$\begin{array}{c}\text { Cohen's } \\
\text { Kappa value }\end{array}$} & \multirow{2}{*}{$\begin{array}{c}\text { Sensitivity } \\
(\%)\end{array}$} & \multirow{2}{*}{$\begin{array}{c}\text { Specificity } \\
(\%)\end{array}$} & \multirow{2}{*}{$\begin{array}{l}\text { PPV } \\
(\%)\end{array}$} & \multirow{2}{*}{$\begin{array}{l}\text { NPV } \\
(\%)\end{array}$} \\
\hline & & $\begin{array}{c}\text { Negative } \\
\text { no. (\%) }\end{array}$ & $\begin{array}{c}\text { Positive } \\
\text { no. (\%) }\end{array}$ & & & & & & \\
\hline ELISA & $\begin{array}{l}\text { Negative } \\
\text { Positive }\end{array}$ & $\begin{array}{c}157(89.7) \\
1(4.0)\end{array}$ & $\begin{array}{l}18(10.3) \\
24(96.0)\end{array}$ & $<0.0001^{a}$ & 0.664 & 57.1 & 99.4 & 96.0 & 89.7 \\
\hline Microscopy (MZN) & $\begin{array}{l}\text { Negative } \\
\text { Positive }\end{array}$ & $\begin{array}{c}158(87.3) \\
0(0.0)\end{array}$ & $\begin{array}{l}23(12.7) \\
19(100)\end{array}$ & $<0.0001^{b}$ & 0.566 & 45.2 & 100.0 & 100.0 & 87.3 \\
\hline
\end{tabular}

aP-value calculated using chi-square test.

${ }^{\mathrm{b}} P$-value calculated using Fischer's exact test. 


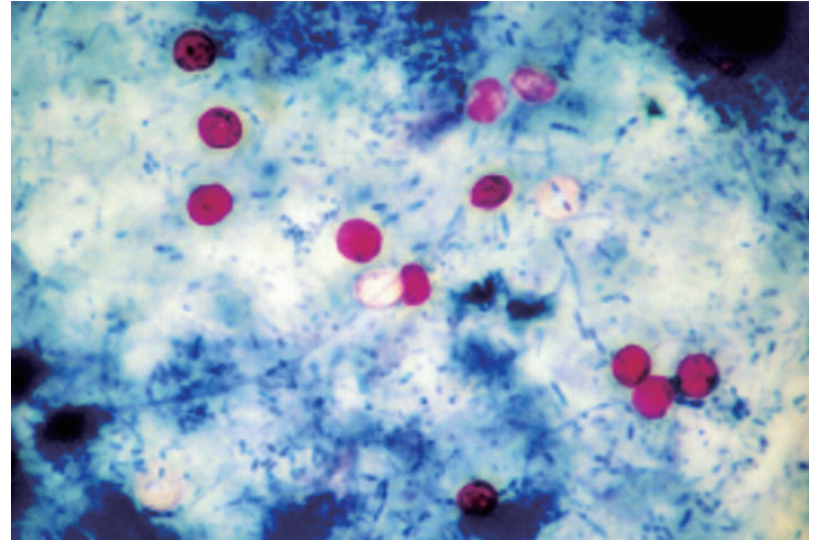

Fig. 3. Cryptosporidium oocysts (MZN stain $\times 1,000)$.

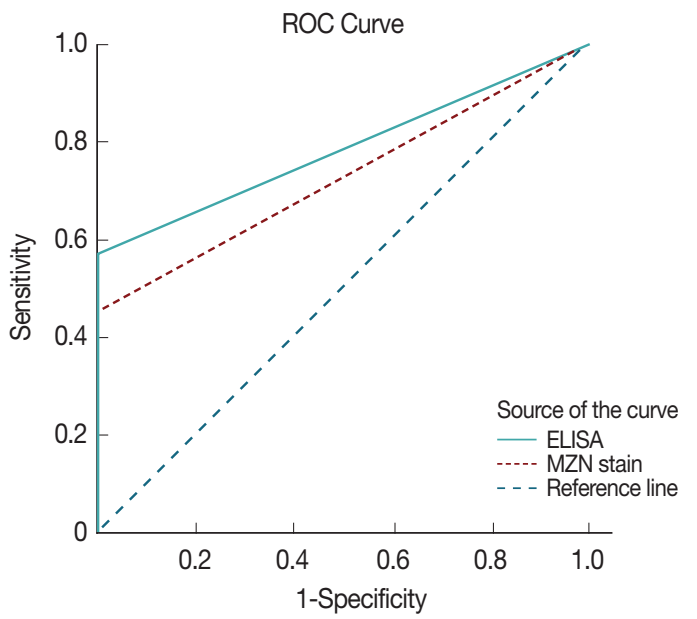

Fig. 4. ROC analysis of sensitivity and specificity of ELISA and microscopy with MZN stain.

sis by MZN stain, Cryptosporidium oocysts were found under microscopic observations (Fig. 3).

ROC with area under the curve analysis was used to test the specificity and sensitivity of both ELISA and direct microscopy in diagnosing cryptosporidiosis. Area under the curve value was 0.78 for ELISA and 0.73 for direct microscopy, respectively indicating both strong test specificity and sensitivity with a $P$ value of $<0.0001$ in both (Fig. 4). However, it is clear from results analysis that both have much inferior sensitivity compared to PCR results.

As seen in Tables 4 and 5, it was noted that adults aged 3140 years had the highest infection rate, followed by those aged 51-60 years. Males were found to be more infected than females ( $22.5 \%$ and $18.8 \%$, respectively). Tap water is found to be associated with higher infection rates, compared to filtered water $(22.7 \%$ and $10.7 \%$, respectively). Patients living in ur-
Table 4. Patient positivity by age groups vs PCR, ELISA, and microscopy using MZN stain

\begin{tabular}{lcccc}
\hline $\begin{array}{l}\text { Stratified } \\
\text { age groups } \\
\text { (year) }\end{array}$ & $\begin{array}{l}\text { ELISA } \\
\text { positive } \\
\text { no. (\%) }\end{array}$ & $\begin{array}{c}\text { PCR } \\
\text { positive } \\
\text { no. (\%) }\end{array}$ & $\begin{array}{c}\text { Microscopic } \\
\text { examination } \\
\text { positive } \\
\text { no. (\%) }\end{array}$ & $\begin{array}{c}\text { MZN stain } \\
\text { positive } \\
\text { no. (\%) }\end{array}$ \\
\hline $1-10$ & $1(9.1)$ & $1(9.1)$ & $2(18.2)$ & $0(0.0)$ \\
$11-20$ & $3(11.1)$ & $6(22.2)$ & $8(29.6)$ & $3(11.1)$ \\
$21-30$ & $5(12.2)$ & $6(14.6)$ & $9(22.0)$ & $2(4.9)$ \\
$31-40$ & $7(19.4)$ & $14(38.9)$ & $11(30.6)$ & $9(25.0)$ \\
$41-50$ & $2(5.7)$ & $4(11.4)$ & $11(31.4)$ & $1(2.9)$ \\
$51-60$ & $6(20.7)$ & $8(27.6)$ & $7(24.1)$ & $3(10.3)$ \\
$>60$ & $1(4.8)$ & $3(14.3)$ & $6(28.6)$ & $1(4.8)$ \\
Total & $25(12.5)$ & $42(21.0)$ & $54(27.0)$ & $19(9.5)$ \\
$P$-value & $0.38^{\mathrm{a}}$ & $0.05^{\mathrm{b}}$ & $0.9^{\mathrm{b}}$ & $0.03^{\mathrm{a}}$ \\
\hline
\end{tabular}

${ }^{a} P$-value calculated using likelihood ratio.

${ }^{\mathrm{b}} P$-value calculated using chi square test.

Table 5. Association between patients' data and positivity by PCR results

\begin{tabular}{|c|c|c|c|c|}
\hline & & $\begin{array}{l}\text { No. positive } \\
(\%)\end{array}$ & $\begin{array}{l}\text { No. negative } \\
(\%)\end{array}$ & $P$-value \\
\hline Gender & $\begin{array}{l}\text { Male } \\
\text { Female }\end{array}$ & $\begin{array}{l}93(77.5) \\
65(81.3)\end{array}$ & $\begin{array}{l}27(22.5) \\
15(18.8)\end{array}$ & $0.6^{a}$ \\
\hline Residence & $\begin{array}{l}\text { Urban } \\
\text { Rural }\end{array}$ & $\begin{array}{l}63(77.8) \\
95(79.8)\end{array}$ & $\begin{array}{l}18(22.2) \\
24(20.2)\end{array}$ & $0.7^{\mathrm{a}}$ \\
\hline $\begin{array}{l}\text { Source of } \\
\text { water }\end{array}$ & $\begin{array}{l}\text { Tap water } \\
\text { Filtered water }\end{array}$ & $\begin{array}{r}133(77.3) \\
25(89.3)\end{array}$ & $\begin{array}{r}39(22.7) \\
3(10.7)\end{array}$ & $0.1^{\mathrm{a}}$ \\
\hline $\begin{array}{l}\text { Animals at } \\
\text { home }\end{array}$ & $\begin{array}{l}\text { Yes } \\
\text { No }\end{array}$ & $\begin{array}{r}43(78.2) \\
115(79.3)\end{array}$ & $\begin{array}{l}12(21.8) \\
30(20.7)\end{array}$ & $0.86^{\mathrm{a}}$ \\
\hline \multirow[t]{7}{*}{$\begin{array}{l}\text { Associated } \\
\text { symptoms }\end{array}$} & $\begin{array}{l}\text { Abdominal } \\
\text { pain and } \\
\text { vomiting }\end{array}$ & $25(78.1)$ & 7 (21.9) & $0.81^{b}$ \\
\hline & $\begin{array}{l}\text { Abdominal } \\
\text { pain }\end{array}$ & $107(82.3)$ & $23(17.7)$ & \\
\hline & Flatulence & 1 (100.0) & $0(0.0)$ & \\
\hline & $\begin{array}{l}\text { Vomiting and } \\
\text { fever }\end{array}$ & $14(87.5)$ & $2(12.5)$ & \\
\hline & $\begin{array}{l}\text { Abdominal } \\
\text { pain and } \\
\text { flatulence }\end{array}$ & $5(50.0)$ & $5(50.0)$ & \\
\hline & $\begin{array}{l}\text { Abdominal } \\
\text { pain, vomiting } \\
\text { and fever }\end{array}$ & $0(0.0)$ & $1(100.0)$ & \\
\hline & $\begin{array}{l}\text { Abdominal } \\
\text { pain and } \\
\text { tenesmus }\end{array}$ & $6(60.0)$ & $4(40.0)$ & \\
\hline
\end{tabular}

${ }^{a} P$-value calculated using chi-square test.

${ }^{\mathrm{b} P}$-value calculated using likelihood ratio.

ban areas, with animal contact had higher infection rates, too.

Other parasites were also discovered during the microscopic examination of the stool samples (Table 6). Ten of the cases infected with G. lamblia and 3 E. histolytica cases were also positive for Cryptosporidium. 
Table 6. Other parasites detected in stool samples by direct microscopy $(n=200)$

\begin{tabular}{lc}
\hline Parasite & No. positive (\%) \\
\hline Giardia lamblia & $28(14.0)$ \\
Entamoeba histolytica & $12(6.0)$ \\
Entamoeba coli & $7(3.5)$ \\
Capillaria philippinensis & $5(2.5)$ \\
Hymenolepis nana & $2(1.0)$ \\
Blastocystis hominis & $1(0.05)$ \\
\hline
\end{tabular}

\section{DISCUSSION}

Recently, PCR and immunodiagnostic methods have become more popular in diagnosis of cryptosporidiosis to overcome the limitations of microscopy. Compared with microscopy, DNA-based detection methods display several advantages such as an increased sensitivity and specificity, the possibility for molecular typing and an optimized turnaround time $[27,32,33]$. Given these trends in diagnosis, PCR was chosen the gold standard in this study. Indeed, it yielded the highest detection rates (21\%), compared to ELISA (12.5\%) and examination of MZN stained slides (9.5\%) and this was found to be statistically significant. In accordance with previous works, findings of this study reaffirm the superiority of PCR in detection of Cryptosporidium in stool samples over immunodiagnosis and direct microscopy. PCR has a reported specificity of up to $100 \%$, therefore, stool samples with oocyst-like bodies in MZN stained smears, but failed to yield specific PCR amplification are deemed negative. True, PCR nearly annuls chances of false positive results, however, this cannot be totally excluded $[24,27,33,34]$. Nevertheless, microscopy and ELISA are not likely to be excluded in field studies and laboratory lacking molecular diagnosis technology, especially in underdeveloped countries, due to their high specificity.

Beni-Suef is one of the less privileged governorates of Upper Egypt, with over 2 million inhabitants, about $80 \%$ of which live in rural areas [35], with substandard housing and drinking water condition, and most have domestic animals and pets in the vicinity. Infectious diseases, including cryptosporidiosis, are frequent there, being largely waterborne and zoonotic $[19,25]$.

In Beni-Suef, an overall Cryptosporidium detection rate of $19 \%$ in human samples using MZN stains was previously reported [25]. Interestingly, the very same infection rate was obtained in the current study by using microscopy with MZN.
Thus, it seems cryptosporidiosis in Beni-Suef has had a rather stable transmission patterns in recent years, even with an overall infection rate of 21\%, according to PCR results.

Previously, it was stated that in humans, the highest prevalence of Cryptosporidium was in infants (31.3\%) and diarrheic individuals (21.1\%) [25]. As infants were not enrolled in this work and all patients were diarrheic, any comparison could not be made in this respect. Young adults were the most infected (31-40 years age group), followed by those aged 51 to 60 years. Needless to say, Infection rates by age and location differ around the world. For example, recently in a location in China the highest rate was found in 40-50 years age group, followed by elderly patients [36]. Environmental, hygiene and other epidemiological factors are involved in such variations. Cryptosporidiosis is classically regarded as particularly more common in children $[19,37]$. However, recent evidence suggests not to overlook it in adult and elderly diarrheic patients.

In this study, infection rates in males outnumbered females. Both similar and contradicting gender related cryptosporidiosis rates were previously reported; with females being more infected $[38,39]$. Variations in demographics and used diagnostic tests must be put in consideration.

In the current study, no statistically significant difference was found in infection rates comparing rural and urban residence, or the presence of animals at home. This may be explained by the fact that the routes of infection in this locality may be water borne, as $22.7 \%$ of positive cases consumed tap water, which is partially impure, compared to only $10.7 \%$ who reported basically drinking filtered water. Similar lack of statistical significance of the same factors was recently reported [40]. Contaminated food and both zoonotic and anthroponotic transmission cycles cannot be overlooked in an agricultural governorate like Beni-Suef, where urban areas may still be largely underdeveloped, especially in infrastructure, and where domestic animals, pets and stray animals are largely distributed.

The main manifestations of cryptosporidiosis, as reported in the study patients, were basically diarrhea, abdominal pain, vomiting and fever. None of the subjects was a documented immunocompromised case. A few other enteric parasites were detected in the study patients, and may have contributed to the symptoms of some. However, their presence does not seem to affect results of the current study, being of no statistical significance.

In conclusion, molecular diagnosis of human cryptosporidiosis is invariably superior to ELISA and direct microscopy after 
concentration and MZN staining, and remains the gold standard. Cryptosporidiosis remains an important cause of diarrhea in Beni-Suef, both in rural and urban areas, which share many environmental factors that favor transmission. Further studies into the transmission cycles and epidemiology of cryptosporidiosis in the Governorate, as well as characterization and genotyping of the parasites are needed for better management and control.

\section{CONFLICT OF INTEREST}

We have no conflict of interest related to this work.

\section{REFERENCES}

1. Chalmers RM, Davies AP. Mini review: clinical cryptosporidiosis. Exp Parasitol 2010; 124: 138-146.

2. Sponseller JK, Griffiths JK, Tzipori S. The evolution of respiratory cryptosporidiosis: evidence for transmission by inhalation. Clin Microbiol Rev 2014; 27: 575-586.

3. Kotloff KL, Nataro JP, Blackwelder WC, Nasrin D, Farag TH, Panchalingam S, Wu Y, Sow SO, Sur D, Breiman RF, Faruque AS, Zaidi AK, Saha D, Alonso PL, Tamboura B, Sanogo D, Onwuchekwa U, Manna B, Ramamurthy T, Kanungo S, Ochieng JB, Omore R, Oundo JO, Hossain A, Das SK, Ahmed S, Qureshi S, Quadri F, Adegbola RA, Antonio M, Hossain MJ, Akinsola A, Mandomando I, Nhampossa T, Acácio S, Biswas K, O'Reilly CE, Mintz ED, Berkeley LY, Muhsen K, Sommerfelt H, RobinsBrowne RM, Levine MM. Burden and aetiology of diarrhoeal disease in infants and young children in developing countries (the Global Enteric Multicenter Study, GEMS): a prospective, case-control study. Lancet 2013; 382: 209-222.

4. Checkley W, White AC Jr, Jaganath D, Arrowood MJ, Chalmers RM, Chen XM, Fayer R, Griffiths JK, Guerrant RL, Hedstrom L, Huston CD, Kotloff KL, Kang G, Mead JR, Miller M, Petri WA Jr, Priest JW, Roos DS, Striepen B, Thompson RC, Ward HD, Van Voorhis WA Xiao L, Zhu G, Houpt ER. A review of the global burden, novel diagnostics, therapeutics, and vaccine targets for Cryptosporidium. Lancet Infect Dis 2015; 15: 85-94.

5. Steiner TS, Thielman NM, Guerrant RL. Protozoal Agent: What are the dangers for public water supply? Ann Rev Med 1997; 48: 329-340.

6. Obiri-Danso K, Okore-Hanson A, Jones K. The Microbiological quality of drinking water sold on the streets of Kumasi, Ghana. Lttr Appl Microbiol 2003; 37: 334-339.

7. Koneman WE, Allen SD, Janda WM, Schreckenberger PC, Winn WC, Jr. Diagnostic Microbiology. 4th ed, Philadelphia, USA, J. B. Lippincott Williams \& Wilkins. 1992, p 907-909.

8. de la Maza LM, Pezzlo MT, Baron ET. Coloured Atlas of Diagnostic Microbiology, Missouri, USA. Walsworth Press Inc, Mar- celine. 1997, p 175.

9. Le Chevallier MW, Norton WD, Lee RG. Occurrence of Giardia and Cryptosporidium spp. in surface water supplies. Appl Environ Microbiol 1991; 57: 2610-2616.

10. Ryan U, Fayer R, Xiao L. Cryptosporidium species in humans and animals: current understanding and research needs. Parasitology 2014; 141: 1667-1685.

11. Scallan E, Hoekstra RM, Angulo FJ, Tauxe RV, Widdowson MA, Roy SL, Jones JL, Griffin PM. Foodborne illness acquired in the United States-major pathogens. Emerg Infect Dis 2011; 17: 7-15.

12. Roellig DM, Yoder JS, Madison-Antenucci S, Robinson TJ, Van TT, Collier SA, Boxrud D, Monson T, Bates LA, Blackstock AJ, Shea S, Larson K, Xiao L, Beach M. Community Laboratory Testing for Cryptosporidium: Multicenter Study Retesting Public Health Surveillance Stool Samples Positive for Cryptosporidium by Rapid Cartridge Assay with Direct Fluorescent Antibody Testing. PLoS One 2017; 12: e0169915.

13. Cacciò SM, Pozio E. Advances in the epidemiology, diagnosis and treatment of cryptosporidiosis. Expert Rev Anti Infect Ther 2006; 4: 429-443.

14. Chalmers RM, Campbell BM, Crouch N, Charlett A, Davies AP. Comparison of diagnostic sensitivity and specificity of seven Cryptosporidium assays used in the UK. J Med Microbiol 2011; 60: 1598-1604.

15. Garcia LS, Shimizu RY. Evaluation of nine immunoassay kits (enzyme immunoassay and direct fluorescence) for detection of Giardia lamblia and Cryptosporidium parum in human fecal specimens. J Clin Microbiol 1997; 35: 1526-1529.

16. Doganci T, Araz E, Ensari A, Tanyuksel M, Doganci L. Detection of Cryptosporidium parrum infection in childhood using various techniques. Med Sci Monit 2002; 8: 223-226.

17. Jayalakshmi J, Appalaraju B, Mahadevan K. Evaluation of an enzyme-linked immunoassay for the detection of Cryptosporidium antigen in fecal specimens of HIV/AIDS patients. Indian J Pathol Microbiol 2008; 51: 137-138.

18. Agnamey P, Sarfati C, Pinel C, Rabodoniriina M, Kapel N, Dutoit E, Garnaud C, Diouf M, Garin JF, Totet A, Derouin F. Evaluation of four commercial rapid immunochromatographic assays for detection of Cryptosporidium antigens in stool samples: a blind multicenter trial. J Clin Microbiol 2011; 49: 1605-1607.

19. Fathy MM, Abdelrazek NM, Hassan FA, El-Badry AA. Molecular copro-prevalence of Cryptosporidium in Egyptian children and evaluation of three diagnostic methods. Indian Pediatr 2014; 51: 727-729.

20. Weitzel T, Dittrich S, Möhl I, Adusu E, Jelinek T. Evaluation of seven commercial antigen detection tests for Giardia and Cryptosporidium in stool samples. Clin Microbiol Infect 2006; 12: 656659.

21. Sturbaum GD, Reed C, Hoover PJ, Jost BH, Marshall MM, Sterling CR. Species-specific, nested PCR-restriction fragment length polymorphism detection of single Cryptosporidium parvum oocysts. Appl Environ Microbiol 2001; 67: 2665-2668. 
22. Abe N, Matsubayashi M, Kimata I, Iseki M. Subgenotype analysis of Cryptosporidium parrum isolates from humans and animals in Japan using the 60-kDa glycoprotein gene sequences. Parasitol Res 2016; 99: 303-305.

23. Skotarczak B. Progress in the molecular methods for the detection and genetic characterization of Cryptosporidium in water samples. Ann Agric Environ Med 2010; 17: 1-8.

24. Laude A, Valot S, Desoubeaux G, Argy N, Nourrisson C, Pomares $\mathrm{C}$, Machouart $\mathrm{M}$, Le Govic $\mathrm{Y}$, Dalle F, Botterel F, Bourgeois N, Cateau E, Leterrier M, Le Pape P, Morio F. Is real-time PCRbased diagnosis similar in performance to routine parasitological examination for the identification of Giardia intestinalis, Cryptosporidium parnum/Cryptosporidium hominis and Entamoeba histolytica from stool samples? Evaluation of a new commercial multiplex PCR assay and literature review. Clin Microbiol Infect 2016; 22: 190.e1-190.e8.

25. Ibrahim MA, Abdel-Ghany AE, Abdel-Latef GK, Abdel-Aziz SA, Aboelhadid SM. Epidemiology and public health significance of Cryptosporidium isolated from cattle, buffaloes, and humans in Egypt. Parasitol Res 2016; 115: 2439-2448.

26. Mary C, Chapey E, Dutoit E, Guyot K, Hasseine L, Jeddi F, Menotti J, Paraud C, Pomares C, Rabodonirina M, Rieux A, Derouin F. Multicentric Evaluation of a New Real-Time PCR Assay for Quantification of Cryptosporidium spp. and Identification of Cryptosporidium parvum and Cryptosporidium hominis. J Clin Microbiol 2013; 51: 2556-2563.

27. Uppal B, Singh O, Chadha S, Jha AK. A comparison of nested PCR assay with conventional techniques for diagnosis of intestinal cryptosporidiosis in AIDS cases from northern India. J Parasitol Res 2014; 2014: 706105.

28. Vanathy K, Parija SC, Mandal J, Hamide A, Krishnamurthy S. Detection of Cryptosporidium in stool samples of immunocompromised patients. Trop Parasitol 2017; 7: 41-46.

29. Casemore D, Armstrong M, Sands R. Laboratory diagnosis of cryptosporidiosis. J Clin Pathol 1985; 38: 1337-1341.

30. Pedraza-Díaz S, Amar C, Nichols GL, McLauchlin J. Nested polymerase chain reaction for amplification of the cryptosporidium oocyst wall protein gene. Emerg Infect Dis 2001; 7: 49-56.

31. Spano F, Putignani L, McLauchlin J, Casemore DP, Crisanti A.
PCR-RFLP analysis of the Cryptosporidium oocyst wall protein (COWP) gene discriminates between C. wrairi and C. parrum, and between $C$. parvum isolates of human and animal origin. FEMS Microbiol Lett 1997; 150: 209-217.

32. McHardy IH, Wu M, Shimizu-Cohen R, Couturier MR, Humphries RM. Detection of intestinal protozoa in the clinical laboratory. J Clin Microbiol 2014; 52: 712-720.

33. Verweij JJ and Stensvold CR. Molecular testing for clinical diagnosis and epidemiological investigations of intestinal parasitic infections. Clin Microbiol Rev 2014; 27: 371-418.

34. Becker SL, Müller I, Mertens P, Herrmann M, Zondie L, Beyleveld L, Gerber M, du Randt R, Pühse U, Walter C, Utzinger J. PCR-based verification of positive rapid diagnostic tests for intestinal protozoa infections with variable test band intensity. Acta Trop 2017; 174: 49-55.

35. Egypt data portal. Egypt Census Data, 2015 [Internet]; [cited 2017 June 28]. Available from: http://egypt.opendataforafrica. org/tadpaqg/egypt-census-data.

36. Yang Y, Zhou YB, Xiao PL, Shi Y, Chen Y, Liang S, Yihuo WL, Song XX, Jiang QW. Prevalence of and risk factors associated with Cryptosporidium infection in an underdeveloped rural community of southwest China. Infect Dis Poverty 2017; 6: 2 .

37. Mor SM, Tzipori S. Cryptosporidiosis in children in sub-saharan Africa: a lingering challenge. Clin Infect Dis 2008; 47: 915-921.

38. Walana W, Tay SCK, Tetteh P, Ziem JB. Prevalence of intestinal protozoan infestation among primary school children in urban and peri-urban communities in Kumasi, Ghana. Sci J Public Health 2014; 2: 52-57.

39. Mathew AO, David OO, Olubunmi FI, Mosunmola OJ, Tiamiyu AR, Gbenga AO. Infection rate of Cryptosporidium parrum among diarrhoea children in Ibadan, Oyo State, Nigeria. Sch J App Med Sci 2014; 2: 3127-3131.

40. Berahmat R, Mahami-Oskouei M, Rezamand A, Spotin A, Aminisani N, Ghoyounchi R, Madadi S. Cryptosporidium infection in children with cancer undergoing chemotherapy: how important is the prevention of opportunistic parasitic infections in patients with malignancies? Parasitol Res 2017; 116: 25072515. 
